\title{
ORAL TRADITION OF KOLOLI KIE AS A CULTURAL LEARNING RESOURCE FOR THE ISLAND TERNATE COMMUNITY
}

\author{
Sarmina $\mathrm{Ati}^{*}$ \\ STKIP Kie Raha Ternate, Maluku Utara, Indonesia
}

\begin{tabular}{ll} 
A R T I C L E I N F O & A B S T R A C T \\
\cline { 2 - 2 } $\begin{array}{l}\text { Keyword: } \\
\text { Oral Tradition, } \\
\text { Culture, } \\
\text { Kolie Kie, } \\
\text { Environment, } \\
\text { Vygotsky }\end{array}$ & $\begin{array}{l}\text { So far, the function of oral tradition is only considered normatively and judged as } \\
\text { something static. But with the demands of globalization, the function of oral tradition } \\
\text { should have been changed to be practical. One form of oral tradition that is still considered } \\
\text { to have values that are still relevant to the needs of community supporters who carried on } \\
\text { from generation to generation is a traditional ceremony. One of the traditional ceremonies } \\
\text { owned by the people of Ternate is kolie kie. Although in reality only a small part of Ternate } \\
\text { people who still hold this ceremony, namely the people who are in the sub-district of } \\
\text { Ternate Islands. The content of cultural values and meaning in the tradition of kololi kie } \\
\text { can also be a source or medium of cultural learning for the community of the island of } \\
\text { Ternate. Real learning is a process of improving a person's cognitive done in the classroom } \\
\text { only, can also be obtained by utilizing the environment as a target for learning, learning } \\
\text { resources, and learning tools. One of the learning theories that accommodate the demands } \\
\text { of sociocultural-revolution or an environment-based learning style is the theory of learning } \\
\text { developed by Vygotsky. In Vygotsky's theory, it is argued that the main thing in improving } \\
\text { one's mental functions is derived from the social life or group, and not just from the } \\
\text { individual himself. }\end{array}$
\end{tabular}

\section{INTRODUCTIONS}

Indonesia is a country with diverse ethnic groups that are rich in culture. This is because each tribe basically has different customs, traditions, customs, and cultures (Ridwan \& Wahdian, 2017). Tradition or culture that exists in various tribes in Indonesia born from ancestors with various historical and beliefs and have different cultural values also in every region. one of the traditional forms still practiced by traditional society in various tribes in Indonesia is a traditional ceremony.

The traditional ceremony is one form of oral tradition that is considered to have values that are still relevant to the needs of community supporters who carried on from generation to generation. The traditional ceremony is also a manifestation of human ability to actively self-raise to nature or environment and as a human effort to be able to connect with the spirits of the ancestors. Not many tribes or indigenous people are able to maintain the ritual ceremony of customs to their children and grandchildren. One tribe or society that is able to maintain the ritual ceremony until nowadays is Ternate people although only part of the Ternate community that is located in the island of Ternate North Maluku province which is still carrying out one of the ritual ceremonies that is the Ritual "Kololi Kie" which is usually held by The Sultanate of Ternate. Where this traditional society has Ritual Activities "Kololi Kie" which is a ritual ceremony surrounds or circumnavigate Mount Gamalama while visiting some sacred tombs that exist around the small island that has this volcano.

Kololi Kie tradition is a ritual to pray for the people of Ternate and North Maluku that the Sultan had done for 700 years ago. This ritual is usually done during the Birthday of the Sultan of Ternate when the people of North Maluku hit by natural disasters and when the people of Ternate conflict of conflict.

\footnotetext{
" Corresponding author.

E-mail addresses: Sarminaati92@gmail.com (Sarmina Ati)
}

ISSN : 2597-7385 (Online) - ISLLAC : Journal of Intensive Studies on Language, Literature, Art, and Culture is licensed under Creative Commons Attribution-ShareAlike 4.0 International License (http://creativecommons.org/licenses/BY/4.0/).

71 | ISLLAC : Journal of Intensive Studies on Language, Literature, Art, and Culture 
There are two paths taken in the kie colloquy rite of the sea lane which in the language of Ternate Region is called Kololi Kie Toma Ngolo (Toma means in and Ngolo means Sea) and land route (Kololi Kie Toma Nyiha (Nyiha means Land).

In traditional ritual ceremony tradition of kololi kie there are several categories when viewed from the aspect of intention or celebration. This categorization is divided into three parts, namely: individual celebrations, group celebrations and a great celebration of the sultanate. The essence of kiean celebration is gratitude for the granting of favors from God as the creator or requesting the protection and salvation of God with the symbolization on Gamalama mountain. In addition, the oral tradition of colloidal kie contains the value and significance for the life of ternate society, because it is considered as a cultural value that can bring safety.

The content of cultural values and meaning in the tradition of colloid kie can also be a source or medium of cultural learning for the community of the island of Ternate. Real learning is a process of improving the cognitive of a person who is dulakukan in the classroom only, can also be obtained by utilizing the environment as a target of learning, learning resources, and learning tools. One of the learning theories that accommodate the demands of sociocultural-revolution or an environment-based learning style is the theory of learning developed by Vygotsky. It is argued that the improvement of one's mental functions comes primarily from his social life or group, and not just from the individual himself (Sumiati \& Asra, 2007).

The function of oral traditions that are only tolerated normatively but in its development can be practical by utilizing the theory of learning developed by Vygotsky on environment-based learning. These two things are the authors elaborated into the focus of writing.

\section{TERNATE CULTURE CONCEPT Cultural Concepts}

The word culture comes from buddhayah (Sanskrit), as the plural form of buddhi meaning sense (Koentjaraningrat in Ratna, 2005: 5). So, culture means reason, then become buddhi (singular) or budhaya (compound). Thus, culture is defined as the result of human thought.

Koentjaraningrat (in Safitri, et al., 2007: 374) divides the culture into three forms, namely (1) the form of culture as a complex of ideas, ideas, values, norms, rules and so on; (2) the form of culture as a complex of patterned behavior activity of man in society; and (3) the form of culture as objects of human works.

From some of these descriptions, it can be concluded that culture is the result of human thought or reason covering all aspects of life in society, including knowledge, moral values, customs, and other habits gained by way of learning.

\section{Ternate Culture}

Ternate community when viewed from the aspect of history (including the public in general) previously adhered to the flow of trust dynamism in addition to animist beliefs. Among the beliefs of dynamism is through worship of the mountains. Even the activity until that time is still done by some circles by sticking to the belief system as one source of supernatural powers (supernatural) who can be asked for help to provide safety and welfare of life. This model of worship also shows the existence of Naturvolken community. And this is understandable because of the location of its mukim area on the volcanic island.

The fear of the tremendous natural forces derived from the flaming gyre is a hypothesis or temporary answer that serves as the basic source of the occultation. Another assumption that they still believe is that by worship, the magical powers that are in the volcano will not become wrathful, it will even give the welfare to the community like giving natural fertility. Conversely, if not performed worship then the magical forces in the volcano will be wrath and harm people or the local community with its eruptions and earthquake earth. The worship of the volcano is in addition to the offerings and prayers of help requests, also by paying homage. Worship by climbing to the top of the mountain is called "fere kiye matubu". whereas Worship by walking around the mountain is called kololi kie.

Nevertheless, the worship of mountains in this tradition is not identical with the worship of the mountain god. For the great power of the mountain is not personified as an extraordinary being or as a god. They did not know the gods but the worship of the mountain mrupakan one of the original beliefs of the ancestors of the ancestors of Indonesia which traces up to now still appear in various corners of the country.

The old belief is so deeply rooted in people's lives that once they embrace Islam, they are still faithful to their ancestral traditions. The Sultans (after the Islamic period) after being crowned, are obliged 
to perform the kololi kie and fere kie matubu ceremony. It's just that the prayer kie is no longer shown to the magical power of volcanoes just kie pray is no longer shown to the magical power of the volcano but to the Gift of Allah SWT. In fact, there are some people who have an individual intention will ask for prayer by doing the tradition of kololi kie and fere kie matubu.

\section{THE CONCEPT OF TRADITIONAL CEREMONY OF KOLOLI KIE Traditional Ceremony}

According Koentjaraningrat (1980: 140) Traditional ceremony is a system of activities or series or actions that are arranged by custom or law that applies in the community associated with various kinds of events that usually occur in the community concerned. The types of ceremonies in public life include birth ceremonies, marriage ceremonies, burial ceremonies and inauguration ceremonies. The ceremony, in general, has a sacred value by the culture supporters. The traditional ceremony is a ceremony that is hereditarily done by supporters in an area. Thus each region has its own custom ceremonies-its own customary ceremonies such as marriage, birth and death and others.

\section{Kololi Kie}

The customs in Ternate have the normative values or norms that govern the relationship of man with the khalik, the relationship between the community and the leadership, in turn also regulate the relationship between leaders with society and public relations with the community, in implementing the customary order which is dominating the life of society is the application of " adat se atorang ". By him in every order of the region has the characteristics of each foreigner in the tradition, the indigenous population of the island in particular must have heard and know the meaning of the word "Kololi Kie" is a ritual activity of traditional society to around or around the mountain gamalama while visiting the sacred tombs adiaek around the island small that has this volcano. The word Kololi Kie comes in two words: Kololi and Kie. Kololi means around or around whereas kie meaning mountain, island or also land, general understanding of traditional ceremony kolie kie is a ritual tradition to circle or surround the mountains while visiting the grave or sacred commonplace in sebutjere or ancestral graves where who had struggled in spreading Islamic Shari'a in Ternate.

\section{THE CONCEPT OF LEARNING VYGOTSKY}

The concept of learning Vygotsy accommodates the demands of sociocultural-revolution. He says that one's way of thinking must be understood from its socio-cultural and historical background. That is, to understand a person's mind rather than by tracing what lies behind his brain and at the depths of his soul, but from the origin of his conscious actions, from the social interactions that are based on his life history (Moll \& Greenberg, 1990).

Vygotsky also explains in his theory of learning that the improvement of one's mental functions derives from his social life or group, and not from the individual himself. Such social interactions are, among other things, closely related to the activities and language used. The key to understanding the social-environmental and psychological processes of humans is the signs or symbols that serve as mediators (Wertsch, 1990). The signs or symbols are the product of the socio-cultural environment in which a person is located.

The theoretical mechanisms he uses to specify the relationship between socio-cultural approach and mental functioning are based on the theme of semiotic mediation, meaning that the signs or symbols and their meanings serve as mediators between rationality in socio-cultural and human approaches where the mental process proceeds (Moll, 1994).

According to Vygotsky, the acquisition of knowledge and cognitive development of a person in accordance with the theory of sociogenesis. The dimensions of social consciousness are primary, while the individual dimensions are derivative or derivative and of a secondary character (Palincsar, Wertsch \& Tulviste, in their Supratics, 2002). That is, individual cognitive knowledge and development can also come from social sources outside of itself. This does not mean that the individual is passive in his cognitive development, but Vygotsky also emphasizes the importance of an individual's active role in constructing his knowledge. So the theory of Vygotsky is actually more appropriately called the co-constructivism approach. That is the cognitive development of a person besides being determined by the individual himself actively, also by an active social environment as well.

One of Vygotsky's major theories relating to the important concept of sociogenetic theory of sociocultural-revolutionary cognitive development in learning and learning theory is the genetic law of development. According to Vygotsky in this theory, each person's ability will grow and develop over two levels, namely: Social tariff in which people form their social environment (can be categorized as 
interpsychological or instrumental); and psychological level within the person concerned (can be categorized as intrapsychological or intramental). This view of theory places the instrumental or social environment as a primary and constitutive factor in the formation of knowledge and cognitive development of a person. He says that higher mental functions within a person will arise and come from their social life. Meanwhile, intramental functions are seen as derivations or descendants that grow or form through the mastery and internalization of these social processes.

\section{LEARNING IN KOLOLI KIECULTURE}

The tradition of kololi kie can be regarded as a merger between tradition and religion. Can articulate local culture that has existed since long ago combined with religious rituals. A tradition like this, a tradition like this for certain circle is considered as heresy (make something new and has no basis in religion). However, for the people of the ternate archipelago that still carry out this tradition, this is a form of effort that is done to maintain the stability of nature in its territory.

Aside from being a form of effort to maintain the stability of nature in its territory for the people of Ternate, the tradition of kolie kie is also a source of life learning which is a culture for the people of Ternate islands. Through the ritual of visiting the cemetery (Zere) or the ancestors' tombs where the former had struggled in spreading the Shari'a of Islam in Ternate. This ritual is one of a series of rituals of traditional ceremonies of kololi kie, the people of Ternate Islands are taught to never forget the services of the predecessors that make Ternate Society today can enjoy life in Ternate. Through rituals surrounding the city of Ternate by sea and land which the Sultan employs every year, leaders are taught to always look directly at his territory, to check whether his leadership is going well or to cause damage to nature and the socio-cultural environment, and to teach the Ternate community how good collaboration leaders and those led to the creation of the common good. Next kie colonial tradition for the people of Ternate is also a learning to continue to live alert and maintain the nature of the island of Ternate. namely, the island with a mountain called Gamalama and is a volcano that is still active today.

\section{CONCLUSIONS}

People who are in Ternate Islands is a society that until now still carry out the ritual kolie kie. The ritual ceremony of kololi kie for the ternate community is a ritual process by encircling Gamalama mountain by sea or land route. It is interpreted as a form of effort made to maintain the stability of nature in its territory. Besides kololi kie ritual can also be a source of cultural learning for the people of the island of Ternate. Utilization of the environment by using the theory of learning from Vygotsky can change the ritual function of traditional ceremony kololi kie that had become more dynamic static. From the surroundings of the traditional kololi kie ceremony, the Ternate Archipelago community can learn a few things about their life's cultural significance. The people of Ternate islands can learn to always be humble and not forget themselves, always remembering the services of their ancestors. The people of Ternate islands are also taught about good collaboration between leaders and those led in bringing about the common good. And the last tradition of colloid kie for the people of the archipelago of Ternate is also a learning to continue to live alert and maintain the nature of the island of Ternate.

\section{REFERENCES}

Fraassen, V. (1987). Ternate de Molukken en de Indonesische archiple. University Of Leiden.

Greenberg, J.B. (1994) Creating zones of possibilities: Combining social contexts for instruction. In Moll, L. C., ed. Vygotsky and education: Instructional implications and applications of sociohistorycal psychology. Cambrige: University Press

Moll, L. C., ed. (1994). Vygotsky and education: Instructional implications and applications of sociohistorical psychology. Cambridge: University Press

Ridwan, M., \& Wahdian, A. (2017). Structure, Function and Value the Tradition of Oral Literature in Sumenep Madura. ISLLAC: Journal of Intensive Studies on Language, Literature, Art, and Culture, 1(1), 252-273.

Supratiknya, A. (2002). Service learning, learning from the context of community life: Problem-based learning paradigm, bring together Jean Piaget and Lev Vygotsky. (Yogyakarta: Speech Dies

Tudge, J. Vygotsky. (1994). The zone of proximal development, and peer collaboration: Implications for classroom practice. In Moll, L. C., ed. Vygotsky and education: Instructional implications and applications of sociohistorycal psychology. Cambrige: University Press

74 | ISLLAC : Journal of Intensive Studies on Language, Literature, Art, and Culture 